\title{
Knowledge mobilisation builds local research collaborations for social innovation
}

\author{
David J. Phipps and Stan Shapson
}

Universities seek to maximise the impact of their research by investing in technology commercialisation services but universities fail to support the various impacts of non-commercial research. This paper describes the experience of York University (Toronto, Canada) in developing the institutional capacity to support knowledge mobilisation to maximise the impacts of research from the social sciences and humanities. York works in partnership with local research users to provide enhanced access to research through dedicated support for research collaborations. Grounded in theories of knowledge transfer and exchange, and illustrated with examples, this paper demonstrates how investments in knowledge mobilisation create value for the institution, researchers, graduate students and research partners.

\section{Background: impacts of research}

Innovation is traditionally conceived by governments in terms of economic impact fuelled by research, development and training for careers in science and technology $(\mathrm{S} \& \mathrm{~T})$. This emphasis on S\&T ignores the important impacts that research and training in the social sciences and humanities (SSH) can make to the economy, culture, society and the environment. Clearly, some SSH disciplines are directly related to innovation and economic impact, including law, economics, business and management, industrial relations and education. Other SSH disciplines such as the creative industries that build on SSH disciplines employ a large number of people and have a direct economic impact. In 2006, the Arts and Humanities Research Council (UK) reported that the economic value of the creative industries was $8 \%$ of Gross Domestic Product (GDP) and growing at twice the rate of the British economy (Research Council Economic Impact Group, 2006), and in 1995 the cultural industries in the UK employed 392,000 people (IFACCA, 2005).

The Conference Board of Canada report Valuing culture: Measuring and understanding Canada's creative economy estimates that the economic contribution of the culture sector was CAN $\$ 84.6$ billion in 2007 (Conference Board of Canada, 2008, p 4). In Canada, the total spending on legal, accounting, tax preparation and bookkeeping services (all SSH disciplines) in 2006 was CAN\$13.1 billion. SSH disciplines are thus major direct contributors to the Canadian economy. Furthermore, consistent with a broader conception of the economic impacts of research beyond S\&T, the Organisation for Economic Co-Cooperation and Development (OECD, 2006a, p 9) has identified that: 
the scope of intellectual assets has evolved in recent years from a narrow focus on $R \& D$, patents and trademarks to a broader concept that includes human resources and capabilities, organisational competencies (databases, technology, routines and culture) and 'relational' capital such as organisational structures and processes, and customer and supplier networks.

Apart from these demonstrated economic impacts, $\mathrm{SSH}$ research can also influence public policy and professional practice. Following conversations with Canadian business, community organisations and individuals, the Canadian Policy Research Networks released their report Connecting with Canadians (CPRN, 2008), which outlined five areas of greatest interest to Canadians:

- citizenship;

- diversity and Canadian values;

- $\quad$ productivity and skills;

- health and an ageing population;

- the environment.

It is evident that research can have economic, social, cultural and environmental impacts, and we define these collective impacts as 'social innovation': the creation or application of research and knowledge to develop sustainable solutions to social, environmental and cultural challenges. Social innovation results in more efficient and effective human services, more responsive public policies and greater cultural understanding.

To maximise the impacts of research, universities must develop the institutional capacity to support the transfer of research to individuals and organisations outside of the academy. Since the passage of the US Bayh Dole Act on 12 December 1980 (PL 96-517, Patent and Trademark Act Amendments of 1980), academic institutions in the US have increasingly supported university-industry partnerships through technology transfer. From these US origins, an entire university-based industry has spread worldwide including professional associations such as the US-based Association of University Technology Managers (www.autm.net) and the Alliance for the Commercialization of Canadian Technology (www.acctcanada.ca/), which focus on maximising the economic impact of (mainly) S\&T research. This paper outlines our experiences in developing a university-based Knowledge Mobilization Unit with an institution-wide mandate to support research-based partnerships outside of the current economic impact paradigms of technology commercialisation and industry liaison.

\section{Institutional support for knowledge transfer}

Knowledge transfer is not a new concept. The 19th-century US land grant colleges enshrined 'service to society' as a mandate along with teaching and research (Bonnen, 1998). Today, although many individual researchers collaborate with research user organisations (organisations seeking academic research to inform decision making), few academic institutions have developed the institutional capacity to support research 
collaborations outside of university-industry partnerships. Martha Piper said in her 2002 Killam Lecture:

We must translate our research findings in the human sciences into public policy and social programs.... Knowledge transfer in the human sciences - the transfer of findings into policy and programs - is as important as technology transfer in the engineering and natural sciences. (Piper, 2002, p 2l)

As Martha Piper recognised, there is a need to support the connection between researchers and research users so that research can inform decisions about public policy and professional practice. Researcher-research user collaborations are typically framed in paradigms of civic engagement, community-university partnerships or service learning (Lerner and Simon, 1998) as well as community-based research (Minkler and Wallerstein, 2003) and the majority are project- or unit-, rather than institution-based. York University in Toronto, Canada, like many universities, also has excellent examples of partnered research projects with the ability to mobilise knowledge for social impact. It co-leads the Centre for Excellence in Research in Immigration and Settlement (http://ceris.metropolis.net/), Ontario's Metropolis node and PREVNet (http://prevnet.ca/), a national network of researchers and non-governmental organisations (NGOs) seeking to promote healthy relationships and eliminate violence. York also hosts the Homeless Hub (http://homelesshub.ca), an innovative research library and information centre focusing on homelessness issues in Canada. Building on this rich foundation of project-based, community-engaged research,York (and a few other universities including those cited below) is developing the institutional capacity to support research utilisation for social innovation in the way most universities have developed the capacity to support technology commercialisation for economic innovation.

This institutional capacity is called knowledge mobilisation: a suite of services that enhances the two-way connection between researchers and research users so that research and evidence can inform decisions about public policy and professional practice. Knowledge mobilisation encompasses methods of knowledge transfer, translation and exchange and extends them to include the co-production of knowledge. Knowledge mobilisation turns research into action. Knowledge mobilisation (the how) enables social innovation (the what).

\section{Institutional support for researcher-research user collaboration}

Recently, Sandra Nutley and colleagues from the Research Unit for Research Utilisation (RURU) at the University of Edinburgh (UK) published an in-depth review of the literature on research utilisation. Using evidence (Nutley et al, 2007) includes a chapter on methods to enhance research utilisation but these methods are most often practised at the level of the researcher or the research user or by non-academic organisations seeking to enhance research utilisation within a specific discipline. For example, the Canadian Health Services Research Foundation (CHSRF) 
(www.chsrf.ca/) is a world leader in developing methods to support knowledge transfer and exchange within the health services sector. Work by the York University Knowledge Mobilization Unit (KM Unit) confirms RURU's finding that the majority of efforts aimed at enhancing research utilisation are focused at the level of the research project, research unit or research discipline. Its recent survey of 42 mainly, but not exclusively, Canadian organisations seeking to enhance research utilisation found that $69 \%$ are discipline-specific organisations or research units and another $26 \%$ are non-academic organisations working broadly in research utilisation (www. researchimpact.ca/resources/index.html). Few academic institutions have developed an institution-wide capacity to support research-research user collaboration. Outside of Canada, examples include the University of Brighton (UK) and the University of Wisconsin (US).

Community University Partnership Programme (Cupp) (University of Brighton, UK) Starting with a grant from the Atlantic Philanthropies in 2003, Cupp (www.brighton. ac.uk/cupp/) now receives core funding from the University of Brighton to use academic expertise to address community-based problems and create partnerships between universities and non-university organisations from government and civil society. It operates a research helpdesk that community organisations can call to get connected to academic researchers, community-university research forums and 'speed dating', all designed to make community-university connections around issues of importance to local communities (Hart and Wolff, 2006). Cupp is one way that the University of Brighton is delivering on its aim of Corporate and Civic Engagement as articulated in its Corporate Plan.

University of Wisconsin Extension Program (US) One hundred years ago the University of Wisconsin developed the Wisconsin Idea and extended its mandate from research and teaching to include service to the people of Wisconsin. The Extension Program encompasses lifelong learning and broadcasts of radio and television educational content and also 'address(es) the changing needs of the state and society by applying relevant university research' (www.uwex.edu/about/mission/). One feature of the Extension Program is the County Agents who interact directly with local citizens and organisations, and deliver the services of the Program to local stakeholders (Ward and Stone, 1992).

In Canada, York University (www.yorku.ca) has also developed the institutional capacity to support research-based partnerships between researchers and research users. York partnered with the University of Victoria (www.uvic.ca) and received the first grant from the Canadian federal granting councils to fund institutional, universitybased knowledge mobilisation services. This Intellectual Property Mobilization programme grant was supported by the Social Sciences and Humanities Research Council (SSHRC) and the Canadian Institutes of Health Research (CIHR). SSHRC further supported York's KM Unit with a Knowledge Impact in Society grant, allowing the Unit to work with local and regional organisations, and contribute to social innovation in York Region. ${ }^{1}$ The University of Victoria is working through 
its Knowledge Mobilization Unit located within the Office of Community Based Research to provide similar services to faculty and local communities in Victoria. The two universities operate as a network, sponsoring inter-institutional research and knowledge mobilisation activities. Elsewhere in Canada, The Leslie Harris Centre of Regional Policy and Development of Memorial University of Newfoundland and Labrador coordinates the research outreach activities of the university and supports research-based partnerships and knowledge mobilisation, but its activities are limited to areas of regional policy and development (OECD, 2006b).

It should be noted that there are other excellent examples of universities providing support for community engagement and outreach (Lerner and Simon, 1998; Minkler and Wallerstein, 2003; Watson, 2007) but care must be taken to distinguish between community engagement as part of a research project, research unit or service learning initiative and the development of institutional capacity (akin to technology transfer) to support research-based social innovation and knowledge mobilisation. Almost all academic institutions still lack the capacity to support research utilisation to inform decisions about public policy and professional practice.

\section{York University's Knowledge Mobilization Unit}

The services to York researchers and local research users offered by the KM Unit are grounded in the theory of research utilisation. Lavis and colleagues (2003) identified three ways to enhance research utilisation: producer push, user pull and knowledge exchange. This paradigm includes unidirectional methodologies of knowledge transfer and translation as well as iterative methodologies of knowledge exchange. We have combined these methodologies with the concept of Mode 5 knowledge that is co-produced between researchers and research users (Hart et al, 2008) to define knowledge mobilisation as a suite of services using a diverse array of strategies that connect researchers and research users to enhance research utilisation (Figure 1). It is clear from Figure 1 that community-based research and knowledge mobilisation are closely related in that both seek to use research to effect change. Community-based research is both a methodology and a philosophy of undertaking research, albeit with elements of knowledge mobilisation (Minkler and Wallerstein, 2003). In contrast, knowledge mobilisation is a suite of activities and services available to support research and includes producer push elements such as clear language research summaries that may not involve communities as the driver of the research question.

Core to the KM Unit is the knowledge broker. Knowledge brokers (Lomas, 2007) may be identified by a variety of job titles but as identified by CHSRF they share a common skill set and common tasks (CHSRF, 2003). Key among these skills and tasks is the ability to bring people together and foster collaboration by helping groups communicate and understand each other's needs and abilities. Similar to university-industry liaison, York's knowledge brokers use the full range of knowledge mobilisation methodologies to identify and support connections between researchers and research users. 


\section{Knowledge mobilisation activities and services}

\section{Figure I: Knowledge mobilisation has elements of producer push, user pull, knowledge exchange and co-production}

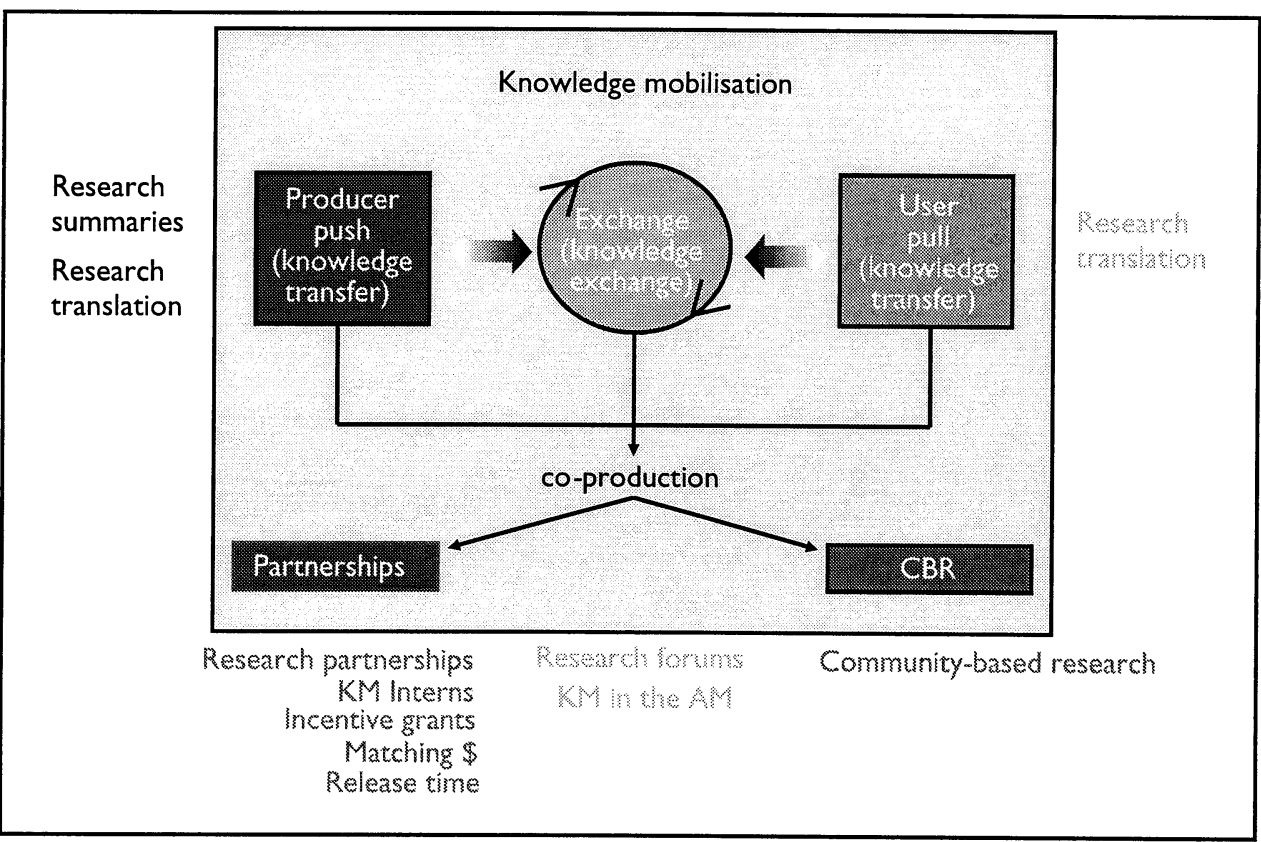

York's knowledge mobilisation services (Table 1) are delivered by the knowledge broker and can be mapped onto producer push, user pull, knowledge exchange and co-production methodologies (Figure 1). The examples in Table 1 illustrate the potential for impact when researchers and research users have the opportunity to exchange ideas and information and are provided with the support necessary to foster sustainable research collaborations resulting in the co-production of research.

\section{Research forums (knowledge exchange)}

' $\mathrm{KM}$ in the AM' is our flagship research forum that has attracted 209 unique participants (many attending multiple meetings), including 99 from community organisations, 47 from the Regional Municipality of York and 63 from York University. KM in the AM is a thematic breakfast meeting that seeks to break down barriers between community and university by placing community on an equal footing with the university.

The community identifies the topic, and the meeting always happens off campus in the community. A presentation is made by a faculty member and a community/ municipality member and lots of time is left afterwards for discussion. While $90 \%$ of participants are satisfied with the presentations and $97 \%$ are satisfied with the discussion, the real measure of success is the degree of informal discussion after the formal session has concluded. Every participant is contacted within three months of the event to identify if there is interest in continuing any conversations started at 


\section{Table I: Knowledge mobilisation services}

\begin{tabular}{|c|c|c|}
\hline KM method & Activity & Comments \\
\hline \multirow[t]{2}{*}{ Producer push } & Research summaries & $\begin{array}{l}\text { Clear language summaries of completed practice and policy relevant research are made available to research users through } \\
\text { web posting, RSS feeds, newsletter and blogs (http://researchimpact.wordpress.com/). Future plans include making these } \\
\text { available in podcast and video formats }\end{array}$ \\
\hline & Research translation & $\begin{array}{l}\text { Provides a single point of entry for researchers seeking to connect with research users. The knowledge broker will 'translate' } \\
\text { the research into policy or practice relevance and will seek to make a match with a research user }\end{array}$ \\
\hline User pull & Research translation & $\begin{array}{l}\text { Provides a single point of entry for research users seeking to connect with researchers. The knowledge broker will 'translate' } \\
\text { the knowledge need into a research question and seek to make a match with a researcher }\end{array}$ \\
\hline $\begin{array}{l}\text { Knowledge } \\
\text { exchange }\end{array}$ & Research forums & $\begin{array}{l}\text { 'KM in the AM' monthly topical breakfast meetings. Topics to date include Mental Health, Immigration and Settlement, Arts } \\
\text { and Culture, Seniors and Ageing, Poverty and Homelessness, Youth Homelessness, Youth in Society, Literacy, Recreation, } \\
\text { Quality of Life in the Workplace; Partnering and Collaboration. }\end{array}$ \\
\hline \multirow[t]{5}{*}{ Co-production } & $\begin{array}{l}\text { Research partnerships } \\
\text { and community-based } \\
\text { research }\end{array}$ & $\begin{array}{l}\text { Database of research expertise and community partners enables identification of possible research-based partners for } \\
\text { opportunities identified through Research Translation (see Inclusivity Action Plan evaluation case study in Box 2). Not all } \\
\text { research-based partnerships will satisfy the criteria of community-based research }\end{array}$ \\
\hline & KM interns & $\begin{array}{l}\text { Graduate students (primarily MA) and a research user partner develop a statement of work and compete for a two- to four- } \\
\text { month paid summer internship (see KM intern case study in Box I, and Table 3) }\end{array}$ \\
\hline & Incentive grants & $\begin{array}{l}\text { Researcher and a research user partner and compete for a CAN\$4,000 grant to seed development of larger, collaborative } \\
\text { grants }\end{array}$ \\
\hline & Release time & $\begin{array}{l}\text { Researcher and a research user partner compete for a half-course release from teaching to allow researcher to devote } 135+ \\
\text { hours to substantive, research-based joint activities }\end{array}$ \\
\hline & Matching/deed funding & $\begin{array}{l}\text { Small amounts of funding are available to seed research/KM opportunities or match funding from research partners to } \\
\text { enhance KM opportunities (see Inclusivity Action Plan evaluation case study in Box 2) }\end{array}$ \\
\hline
\end{tabular}


the event. It then becomes the role of the knowledge broker to support and foster emerging partnerships. As a result of a conversation started at the Mental Health $\mathrm{KM}$ in the AM the Canadian Mental Health Association (CMHA) of York Region became a partner in a CAN $\$ 1.5$ million grant from the Canadian Institutes of Health Research to undertake knowledge mobilisation activities to strengthen pathways to young adult mental health. In this way, the voices of the consumer and community are engaged in every step of the research cycle: development, execution, evaluation and dissemination.

Feedback about KM in the AM has been generally positive:

Stephen Gaetz (Faculty of Education,York University): I think the KM in the AM events have been a huge success. Linking academic researchers with interested community partners isn't an easy thing to do. However, when you see 25 people in a room together, early in the morning, freely engaging ideas about important issues, you know something is working.

HennyWestra (Department of Psychology,York University): I had very low expectations going in [to KM in the AM]. I thought nothing significant would come of it. I was pleasantly surprised and it gave me renewed energy for my project. Bringing together people from different organisations and perspectives is essential to momentum for KM activities.

Mary Lynne Porto (CMHA, York Region): I was excited about the KM in AM session as I believed the collaboration between academics, researchers, frontline staff and consumers offered real potential for knowledge generation and transfer. I remain enthusiastic and hopeful.

\section{Research translation (co-production)}

$\mathrm{KM}$ in the AM serves as an introduction and, along with the KM Unit's Research Translation service (similar to Cupp's Research Help Desk) (Hart et al, 2008), it serves to identify research- and knowledge-based partnerships for social innovation. The first of two knowledge brokers was hired in February 2006 and operations began in autumn 2006. As of 30 April 2008, York had received 44 requests for research from research users (see Table 2) and 15 requests for research partnerships from York faculty. Of these 59 opportunities, 42 have resulted in a successful match between researchers and research users, 11 are pending a match and in six cases no match was made. Of these six cases, two failed because no partner could be identified, two because insufficient notice was provided to identify partners, one because of conflicting demands on the faculty partner, and one because the scope of expectation exceeded the mandate of the KM Unit. 


\section{Research funding leveraged by the KM Unit}

Many large-scale social sciences and humanities grant competitions now require plans for knowledge mobilisation, and the KM Unit provides a unique service to faculty and partners who are preparing grant applications to external funding agencies. A clearly articulated and compelling knowledge mobilisation strategy is only one of many decision criteria for success. However, of 13 large-scale applications involving a KM component and supported by the KM Unit between autumn 2006 and 30 April 2008, seven have been successful, resulting in York securing total agency funding of CAN\$11.62 million. In addition, the university received sponsored research agreements totalling over CAN $\$ 208,500$, which arose solely from relationships brokered through the KM Unit (see Table 2). During this time,York provided direct cash support to the KM Unit and while monitoring the financial return on investment is only one form of measuring impact of research and $\mathrm{KM}$, the funding attracted with the support of the Unit represents a 26.29-fold return (=2,629\%).

Table 2:York University KM activity

\begin{tabular}{|c|c|c|c|c|}
\hline KM activity & 2006 & 2007 & $\begin{array}{l}\text { I January- } \\
30 \text { April } \\
2008\end{array}$ & $\begin{array}{c}\text { Total } \\
2006-08\end{array}$ \\
\hline Partnerships (including KM interns) & 7 & 46 & 12 & 65 \\
\hline Sponsored research agreements & 0 & 6 & II & 17 \\
\hline $\begin{array}{l}\text { Graduate students engaged with } \\
\text { research users }\end{array}$ & 1 & 20 & 63 & 144 \\
\hline $\begin{array}{l}\text { Information sessions for research } \\
\text { users }\end{array}$ & 32 & 82 & 40 & 154 \\
\hline $\begin{array}{l}\text { Information sessions for faculty, } \\
\text { students }\end{array}$ & 32 & 41 & 27 & 100 \\
\hline Hits on website & 284 & 204,000 & 133,876 & 337,876 \\
\hline $\begin{array}{l}\text { Knowledge/research submissions } \\
\text { made to research users }\end{array}$ & 4 & 30 & 9 & 43 \\
\hline $\begin{array}{l}\text { Requests for research from } \\
\text { research users }\end{array}$ & 4 & 24 & 31 & 59 \\
\hline $\begin{array}{l}\text { Funding leveraged via KM Unit } \\
\text { through research contracts }\end{array}$ & 0 & $\$ 57,000^{\mathrm{a}}$ & $\$ 151,500$ & $\$ 208,500$ \\
\hline $\begin{array}{l}\text { Requests for KM support on large- } \\
\text { scale grants }\end{array}$ & 2 & 11 & 0 & 13 \\
\hline $\begin{array}{l}\text { Total funding awarded from grants } \\
\text { with } K M \text { component }\end{array}$ & $\$ 1$ million & $\$ 4.6$ million & $\$ 6.02$ million & $\begin{array}{l}\$ 11.62 \\
\text { million }\end{array}$ \\
\hline
\end{tabular}

Note: ${ }^{a}$ CAN\$

\section{Shared decision making and governance}

It is important to ground the work of the KM Unit in the experiences and expectations of policy makers and community partners. It is equally important to develop institutional partnerships that transcend individual project-related collaborations. Acting on these 
values and principles, York and its decision-maker partners have developed a shared governance model that builds trust and ensures mutual relevance. Decision-maker partners and faculty serve on the KM Unit's Joint Advisory Committee, and the former were not only co-applicants but also funding partners on the university's KM grant applications. The perspectives of decision-maker partners thus infuse the operations and governance of the Unit, enabling knowledge mobilisation activities to serve the diverse needs of local decision makers as well as faculty.

\section{Outcomes and impacts}

The activities of the KM Unit from autumn 2006 to 30 April 2008 are illustrated in Table 2. Many of these numbers represent activities or outputs. Additional analysis will be required to identify outcomes or impacts but two case studies illustrate the benefits to researchers, graduate students and research users of investing in institutional capacity to support knowledge mobilisation.

\section{Box I: KM intern case study}

Tammy Miller was an MA (Communications and Culture) student of Barbara Crow (Director, Graduate Program in Communication and Culture and Department of Sociology, York University) who was undertaking research in digital technology, social movements and the political economy of communication. Ms Miller applied for a summer 2007 KM internship to undertake needs assessments and to understand and inform a communications strategy for Free the Children, a Canadian-based global NGO with a mission to reduce child labour. Free the Children was not aware of how its users were interacting with the website. This study showed Free the Children how and why people were using its online resources and provided a series of recommendations to more effectively engage its target audience. Based on her MA class and thesis work, Ms Miller undertook the research that resulted in a newly designed website (www. freethechildren.com). Free the Children has an appreciation of the value of university expertise, has learned how to work with academic researchers and now has a more effective website. Ms Miller applied her academic expertise to a real-world setting and graduated with both an MA and experience in her field of study. The experiences of this internship also enriched the research programme of her supervisor and of the Communications and Culture Program at York University.

See Table 3 for the diversity of disciplines supported by the KM intern programme and outcomes for those interns for whom data were available. KM internships are a relatively affordable way of creating sustained impact on the graduate student and partner organisation. 


\section{Box 2: Inclusivity Action Plan (IAP) evaluation case study}

York Region launched its IAP in May 2005 as a strategy to provide a diverse array of human services to new Canadians. The KM Unit received a request through the Research Translation service in autumn 2007 for academic expertise to collaborate with the Region on an evaluation of the IAP.York Region funded the work via a research contract with York. The evaluation was initiated in November 2007, results returned in spring 2008 and in June 2008 the Human Services Planning Coalition of York Region used the evidence generated in the evaluation to endorse a recommendation to the Regional Council to continue building an ethnoculturally inclusive York Region and to prepare a plan for the next phase of the IAP before the end of 2008. York's KM Joint Advisory Committee (made up of community and faculty acting as a steering committee) approved matching funds to allow clear language research summaries to be developed from the results of the IAP evaluation, allowing for greater dissemination of the results to other municipalities. Through this research partnership, York Region was able to make an evidence-informed decision, York faculty were able to use the data for publication purposes and other municipalities will be presented with a novel way of delivering human services to new Canadians.

Program Director, Human Services Planning, Regional Municipality of York: "York University's Knowledge Mobilization Unit has established itself as the gateway between human services providers in York Region and researchers from York University. The research expertise and capacity of York University are highly accessible to human services providers for needs assessment, policy/program development as well as program evaluation. York Region is planning to develop its first long range integrated cross-sectoral human services plan. The plan has to be guided by research results and evidence-based information. York University's Knowledge Mobilization Unit will be our key partner for such information."

\section{Lessons learned and future directions}

Over the last two years of building and operating the KM Unit we have come to a number of instructive conclusions:

- Developing an institutional capacity to support knowledge mobilisation (as institutions support technology commercialisation) results in benefits to the institution, researchers, graduate students and research users.

- It takes time to break down community-university barriers and develop trust. Care must be taken to manage expectations on both sides. The KM Unit has been successful in making a match between researchers and research users in $71 \%$ of cases, with another $19 \%$ pending matchmaking, but cannot and does not promise to deliver a successful researcher-research user partnership in every case. 
Table 3: KM interns and partner organisations (summer 2007)

\begin{tabular}{|c|c|c|c|}
\hline $\begin{array}{l}\text { Intern's } \\
\text { academic } \\
\text { programme }\end{array}$ & Community partner & Project theme & Outcomes \\
\hline $\begin{array}{l}\text { Environmental } \\
\text { Studies }\end{array}$ & $\begin{array}{l}\text { The No More } \\
\text { Silence Network }\end{array}$ & Fundraising R\&D & $\begin{array}{l}\text { Intern continues in a voluntary } \\
\text { capacity with partner }\end{array}$ \\
\hline $\begin{array}{l}\text { Environmental } \\
\text { Studies }\end{array}$ & $\begin{array}{l}\text { Interagency } \\
\text { Coalition on AIDS } \\
\text { and Development } \\
\text { (CAD) }\end{array}$ & $\begin{array}{l}\text { National } \\
\text { Forum research } \\
\text { dissemination }\end{array}$ & $\begin{array}{l}\text { Intern continues in a voluntary } \\
\text { capacity with partner, and expects } \\
\text { internship will be a valuable reference } \\
\text { during career development }\end{array}$ \\
\hline Education & $\begin{array}{l}\text { Parkdale Collegiate } \\
\text { Institute }\end{array}$ & $\begin{array}{l}\text { Arts-based } \\
\text { community } \\
\text { building }\end{array}$ & No data available \\
\hline $\begin{array}{l}\text { Environmental } \\
\text { Studies }\end{array}$ & $\begin{array}{l}\text { Sierra Club of } \\
\text { Canada }\end{array}$ & $\begin{array}{l}\text { Recreation park } \\
\text { allocations }\end{array}$ & $\begin{array}{l}\text { Intern continues in a voluntary } \\
\text { capacity with partner and has joined } \\
\text { executive committee of local chapter }\end{array}$ \\
\hline $\begin{array}{l}\text { Environmental } \\
\text { Studies }\end{array}$ & $\begin{array}{l}\text { Toronto Wildlife } \\
\text { Centre }\end{array}$ & $\begin{array}{l}\text { Public education } \\
\text { and outreach }\end{array}$ & $\begin{array}{l}\text { Videos produced for partner } \\
\text { presented on the internet }\end{array}$ \\
\hline Psychology & $\begin{array}{l}\text { New Canadians } \\
\text { Centre } \\
\text { Peterborough }\end{array}$ & $\begin{array}{l}\text { Immigrant need } \\
\text { assessment }\end{array}$ & $\begin{array}{l}\text { Intern continues in a voluntary } \\
\text { capacity with partner and presented } \\
\text { data collected during internship at } \\
\text { national conference }\end{array}$ \\
\hline Fine Arts Film & $\begin{array}{l}\text { George Herman } \\
\text { House }\end{array}$ & $\begin{array}{l}\text { The Self } \\
\text { Portrait Project } \\
\text { for women } \\
\text { with mental } \\
\text { disabilities }\end{array}$ & No data available \\
\hline $\begin{array}{l}\text { Communication } \\
\text { and Culture }\end{array}$ & Free the Children & $\begin{array}{l}\text { Online resource } \\
\text { evaluation }\end{array}$ & $\begin{array}{l}\text { Website redesign for partner } \\
\text { contributed to intern's thesis defence. } \\
\text { Intern and partner are discussing } \\
\text { options for ongoing employment }\end{array}$ \\
\hline Education & $\begin{array}{l}\text { Youth Emergency } \\
\text { Shelter, } \\
\text { Peterborough }\end{array}$ & $\begin{array}{l}\text { Organisational } \\
\text { effectiveness } \\
\text { analysis }\end{array}$ & $\begin{array}{l}\text { In collaboration with intern, } \\
\text { partner secured CAN } \$ 130,000 \text { to } \\
\text { develop Community Outreach and } \\
\text { Development Program }\end{array}$ \\
\hline $\begin{array}{l}\text { Women's } \\
\text { Studies }\end{array}$ & $\begin{array}{l}\text { African Theatre } \\
\text { Ensemble }\end{array}$ & \begin{tabular}{|l|} 
Drama \\
curriculum and \\
educational \\
guide \\
development \\
\end{tabular} & $\begin{array}{l}\text { Intern continues in a voluntary } \\
\text { capacity with partner, and directed } \\
\text { theatrical production for partner }\end{array}$ \\
\hline Geography & $\begin{array}{l}\text { Vietnamese Youth } \\
\text { and Family Social } \\
\text { Services, Toronto }\end{array}$ & $\begin{array}{l}\text { At-risk youth } \\
\text { programme } \\
\text { design }\end{array}$ & No data available \\
\hline Psychology & $\begin{array}{l}\text { Baycrest Centre for } \\
\text { Geriatric Care }\end{array}$ & $\begin{array}{l}\text { Memory } \\
\text { and ageing } \\
\text { programme } \\
\text { evaluation }\end{array}$ & $\begin{array}{l}\text { Intern continues to collect data with } \\
\text { partner for ongoing programme } \\
\text { evaluation, and is preparing a } \\
\text { manuscript }\end{array}$ \\
\hline $\begin{array}{l}\text { Critical } \\
\text { Disability Studies }\end{array}$ & $\begin{array}{l}\text { Ontario } \\
\text { Accessibility } \\
\text { Directorate }\end{array}$ & Policy research & $\begin{array}{l}\text { Intern was hired on contract by } \\
\text { partner organisation }\end{array}$ \\
\hline
\end{tabular}


- The use of broadband technology ${ }^{2}$ to connect stakeholders over distance and over time (if a research video forum is recorded and posted) can facilitate research utilisation over a large geographical area (see, for example, the Aboriginal Policy Research Forum in Table 1).

- We have found that community/government partners are earlier adopters and they use the services of the KM Unit more than York faculty. Indeed, 75\% of requests for partnership arise from research user organisations. One explanation might be that there is little academic reward for engaging in activities that enhance non-academic research impact, and this has previously been identified as a barrier for effective knowledge mobilisation (Meagher et al, 2008). Continued efforts at culture change and faculty leadership will be used to address this imbalance.

- Decision-maker partners must be engaged throughout the planning, funding, delivery and evaluation of the KM Unit. Engaging research user organisations in a substantive fashion develops trust, transcends individual research projects and maximises the relevance and sustainability of the $\mathrm{KM}$ service to local decision makers.

However despite the successes and the lessons learned, a number of challenges and opportunities remain.

First, there is no established, effective way of evaluating knowledge mobilisation: Mitton concluded that 'there is an inadequate evidence base for doing evidencebased knowledge transfer and exchange' (Mitton et al, 2007, p 729). Knowledge mobilisation is a means of creating non-academic impact from university research, and methods of evaluating this type of impact should be instructive. Care must be taken to distinguish between research quality (mainly academic consumption) and research impact (mainly end user uptake of research) but the ability to identify impact is not well developed (Coryn, 2008). Claire Donovan (2007) describes the payback method, which includes quantitative bibliometrics but also contains a qualitative (peer review) process including research users. Australia is incorporating elements of panel review (impact) and quantitative measures (quality) into its Research Quality Framework for national research evaluation (Donovan, 2008) so the payback methodology should serve as a starting point for considering evaluation methodologies for knowledge mobilisation.

Second, knowledge mobilisation is not a monetised transaction. We do not sell our services because if we did it is likely that only large NGOs and some government agencies would be able to participate. Limited overhead funds are attracted through research contracts, and some indirect costs will be generated through receipt of Canadian federal tri-council funded grants. However, allocation of the genesis and distribution of these modest funds to the KM Unit is not feasible with the many other competing demands on them. Knowledge mobilisation is not a self-sustaining activity but neither are most technology transfer offices. Investments in an institutional capacity to support technology commercialisation have been a part of US university budgets for the 27 years since Bayh Dole, with only a few technology transfer offices operating at a profit instead of as a service centre. Universities need to identify a 
sustainable solution for funding knowledge mobilisation as a service to faculty that does not depend on fee for service.

Sustainability also requires that we identify and support research that is relevant to the needs of research users. While allYork researchers have access to support from the KM Unit, not all research will be of strategic importance to local research users. York has strong research expertise in areas such as immigration and settlement (CESIRS), healthy relationships (PREVNet) and homelessness (Homeless Hub) but we need to undertake further needs assessments in consultation with municipal, community and provincial agencies to identify those researchers who have expertise that maps onto the strategic priorities of our research user partners. Identifying areas of mutual strategic importance and forging research collaborations to support the co-production of research that meets strategic priorities will be an important step towards creating a sustainable knowledge mobilisation service.

Funding agencies such as SSHRC and CIHR have recognised the importance of supporting knowledge mobilisation in investigator-driven research projects. However, agencies typically have not supported institutional capacity building in knowledge mobilisation in the same way as they do for technology transfer through funding programmes such as the Ontario Research Commercialization Program (www.mri. gov.on.ca/english/programs/ORC-Program.asp) and the Centres of Excellence in Commercialization and Research (www.nce.gc.ca/comp/CECR/cecr_e.htm). Research funding agencies need to support institutional knowledge mobilisation as they do technology transfer. Institutions need to invest in developing expert knowledge mobilisation services and foundations need to recognise social innovation as an eligible target for support. Only in partnership will academic research maximise its social, cultural, environmental and economic impact on Canadians. York's KM Unit is one example of how working in partnership has tangible and sustained impacts on researchers, graduate students, the university and the wider community.

\section{Conclusion}

Meagher and colleagues (2008) recently identified a number of conditions for generating non-academic impact from social science research. These conditions include creating a two-way interaction between researchers and research users; making knowledge transfer funding, dedicated staff and infrastructure accessible; and communicating clear translations of research findings. With its knowledge brokers, resources and clear language research summaries, the KM Unit has built and implemented these conditions to allow York's research to generate non-academic impacts and contribute to social innovation.

We have shown that developing an institutional capacity for knowledge mobilisation has benefits for the institution, researchers, graduate students and research users. Project-based or discipline-based knowledge mobilisation is well under way in most institutions and organisations but few academic institutions have yet to approach knowledge mobilisation as an institutional capacity in the way that most have invested in technology commercialisation. Taking advantage of the existing expertise of researchers and their community partners is an excellent way of seeding a KM 
Unit but as universities seek to become active members in the many facets of their local communities, KM Units will have to work with local research users to identify and support research that is of mutual strategic importance. The KM Unit at York University is emerging as one model that offers a diversity of knowledge mobilisation services including producer push, user pull, knowledge exchange and co-production to maximise the economic, social, cultural and environmental impact of research. If universities wish to embrace a broad definition of innovation, it is incumbent upon them to work in partnership with research funding organisations to develop the institutional capacity to support knowledge mobilisation as well as technology transfer.

\section{Notes}

${ }^{1}$ York Region (www.york.ca) covers $1,776 \mathrm{sq} \mathrm{km}$ and encompasses nine municipalities north of Toronto, Canada and had a total population of 983,100 in 2007. With a five-year growth rate of $22 \%$ (2001-06) and with new Canadians making up $43 \%$ of the population (almost twice that of Ontario), York Region is one of Canada's fastest-growing and most diverse communities. It has elements of inner city (ie downtown Markham), high wealth creation (ie Vaughn), an Aboriginal reserve (in Georgina), rural agriculture (ie East Gwillimbury) and environmentally protected areas such as the Townships of King and Whitchurch-Stouffville.

2 We used broadband video technology to connect researchers from four universities with policy makers and community perspectives on Aboriginal policy research questions (health, education and economic outcomes; models of Aboriginal/government relations; Aboriginal NGOs as agents of social, cultural and economic renewal) identified by the Ontario Public Service. A summary of the Aboriginal Policy Research Forum may be found at www.researchimpact.ca/successstories/aboriginal/index.html and complete proceedings may be viewed at www.researchimpact.ca/successstories/aboriginal/videos/ index.html.

\section{Acknowledgements}

This work was funded through the generous support of the Social Sciences and Humanities Research Council of Canada, the Canadian Institutes of Health Research, theYork Region District School Board, the Regional Municipality of York and York University. We wish to thank the staff of the KM Unit - Michael Johnny and Krista Jensen for data collection and Sarah Flicker, David Dewitt and Michaela Hynie for useful critical feedback on the manuscript. We would also like to thank our collaborators at the University of Victoria - Richard Keeler, Budd Hall and Laura Milne. 


\section{References}

Bonnen, J.T. (1998) 'The land-grant idea and the evolving outreach university', in R.M. Lerner and L.A.K. Simon (eds) University-community collaborations for the 21st century: Outreach scholarship for youth and families, New York: Garland Publishing, pp 25-70.

CHSRF (Canadian Health Services Research Foundation) (2003) The theory and practice of knowledge brokering in Canada's health system: $A$ report based on a CHRSF national consultation and a literature review, Ottawa: CHSRF, www.chsrf.ca/brokering/ pdf/Theory_and_Practice_e.pdf

Conference Board of Canada (2008) Valuing culture: Measuring and understanding Canada's creative economy, www.conferenceboard.ca/documents.aspx?did=2671

Coryn, C.L.S. (2008) Models for evaluating scientific research: $A$ comparative analysis of national systems, Saarbrucken:VDM Verlag Dr Müller, p 372.

CPRN (Canadian Policy Research Networks) (2008) Connecting with Canadians: Shaping our future, Ottawa: CPRN, www.cprn.org/documents/49902_EN.pdf

Donovan, C. (2007) 'The qualitative future of research evaluation', Science and Public Policy, vol 34, no 8, pp 585-97.

Donovan, C. (2008) 'The Australian Research Quality Framework: a live experiment in capturing the social, economic, environmental, and cultural returns of publicly funded research', New Directions for Evaluation, no 118, pp 47-60.

Hart, A. and Wolff, D. (2006) 'Developing local "communities of practice" through local community-university partnerships', Planning, Practice and Research, vol 21, no 1, pp 121-38.

Hart,A., Maddison, E. and Wolff, D. (2008) Community-university partnerships in practice, Leicester: National Institute of Continuing Education, $\mathrm{p} 6$.

IFACCA (International Federation of Arts Councils and Culture Agencies) (2005) Statistical indicators for arts policy, D'Art Report 18, Sydney: IFACCA, www.ifacca. org/media/files/statisticalindicatorsforartspolicy.pdf

Lavis, J., Ross, S., McLeod, C. and Gildner, A. (2003) 'Measuring the impact of health research: assessment and accountability in the health sector', Journal of Health Services Research and Policy, vol 8, no 3, pp 165-70.

Lerner, R.M. and Simon, L.A.K. (eds) (1998) University-community collaborations for the 21st century: Outreach scholarship for youth and families, New York: Garland Publishing.

Lomas, J. (2007) 'The in-between world of knowledge brokering', British Medical Journal, vol 334, no 7585, pp 129-32.

Meagher, L., Lyall, C. and Nutley, S. (2008) 'Flows of knowledge, expertise and influence: a method for assessing policy and practice impacts from social science research', Research Evaluation, vol 17, no 3, pp 163-73.

Minkler, M. and Wallerstein, N. (eds) (2003) Community-based participatory research for health, San Francisco, CA: Jossey-Bass.

Mitton, C.,Adair, C.E., McKenzie, E., Patten, S.B. and Perry, B.W. (2007) 'Knowledge transfer and exchange: review and synthesis of the literature', Milbank Quarterly, vol 85, no 4, pp 729-68. 
Nutley, S.M., Walter, I. and Davies, H.T.O. (2007) Using evidence: How research can inform public services, Bristol: The Policy Press.

OECD (Organisation for Economic Co-operation and Development) (2006a) Creating value from intellectual assets, Paris: OECD, www.oecd.org/dataoecd/53/19/36701575. pdf

OECD (2006b) Supporting the contribution of higher education institutions to regional development: Peer review report: Atlantic Canada, Paris: OECD, www.oecd.org/ dataoecd/35/59/38455547.pdf

Piper, M. (2002) Building a civil society: A new role for the human sciences, 2002 Killam Annual Lecture, Halifax, Nova Scotia: Killam Trusts, www.killamtrusts.ca/docs/ Killam_Lec_02.pdf

Research Council Economic Impact Group (2006) Increasing the economic impact of research councils: Advice to the Director General of Science and Innovation, DTI from the Research Council Economic Impact Group, 06/178, Swindon: Research Council Economic Impact Group, www.grad.ac.uk/downloads/documents/Reports/ National\%20policy\%20section/Warry\%20report.pdf

Ward, D. and Stone, K. (1992) 'Serving the state: the Wisconsin Idea revisited', Educational Record, vol 73, no 2, pp 12-16.

Watson, D. (2007) Managing civic and community engagement, Maidenhead: Open University Press.

David J. Phipps, Research Services \& Knowledge Exchange and Adjunct Faculty, Faculty of Graduate Studies, York University, Toronto, Ontario, Canada, dphipps@yorku.ca

Stan Shapson, Research \& Innovation, York University, Toronto, Ontario, Canada, sshapson@edu.yorku.ca 